\title{
Efficacy evaluation of new hemoglobin E screening test in community hospitals
}

\author{
Yuttana Sudjaroen \\ Faculty of Science and Technology, Suan Sunandha Rajabhat University, Bangkok, 10300 Thailand.
}

Received 1 April, 2014; Accepted 13 June, 2014

\begin{abstract}
The objective of the research was to evaluate of the efficacy of new HbE screening test (E-Sure, Mitr Medical, Thailand) compared to the modified 2,6 dichlorophenol indophenols precipitation test (KKUDCIP) and results were confirmed by capillary electrophoresis. Blood samples were collected from patients who came for physical examinations at Kutchap Hospital and hospitals with inter-laboratory cooperation from October 2013 to February 2014. The samples were screened for those with mean corpuscular volume (MCV) lower than normal (MCV < $80 \mathrm{fl}$ ), resulting in 326 samples. After screening and confirming for $\mathrm{HbE}$ carriers, 226 cases of $\mathrm{HbE}$ carriers were found, including $234 \mathrm{HbE}$ trait and 32 homozygous HbE carriers. When the efficacy of KKU-DCIP screening method was compared to that of the HbE screening test (E-Sure) in community hospitals, it was found that the KKU-DCIP test had sensitivity, specificity, positive predictive, negative predictive and efficiency values of 95.1, 91.6, 98.1, 80.9 and $94.5 \%$, respectively. Whereas, HbE screening test, which had sensitivity, specificity, positive predictive, negative predictive and efficiency values of 99.2, 96.7, 99.2, 96.7 and $98.8 \%$, respectively. The $\mathrm{HbE}$ screening test is higher efficacy, as well as being more convenient and easier to interpret, which is suitable for HbE carrier screening in community hospital laboratories.
\end{abstract}

Key word: Thalassemia, hemoglobin E, screening method, hemoglobin E carrier.

\section{INTRODUCTION}

Thalassemia is a genetic abnormality that causes abnormal hemoglobin production by less globin chain protein. The red blood cells are abnormal in size and shape, which prone to destruction. Many abnormal thalassemia gene types are found in Thailand. The convergence of these genes causes abnormality and varying levels of pathological severity, ranging from showing no symptoms at all to the highest severity, which causes fetal death or death at birth (Wasi, 1981; Fucharoen and Winichagoon, 1992). The Public Health
Department announced a national policy to promote the prevention and control of thalassemia and abnormal hemoglobin, considering it a basic right of pregnant women and their husbands to receive screening services and confirmation of whether or not the couple is at risk of having a child with severe thalassemia. Every positive case would receive the service to prenatal diagnose before birth giving. So, each service center must organize the service system according to standard.

$\mathrm{HbE}$, this is structurally abnormal hemoglobin where 
the $\beta$-globlin chain $\left(\alpha_{2} \beta_{2}{ }^{E}\right)$ is induced by G-A substitution at codon 26 of the $\beta$-globlin gene, causing the amino acids changing the location from glutamate to lysine (Weatherall and Clegg, 2001a; Weatherall and Clegg, 2001b). Generally, heterozygous-type HbE carriers do not have anemia, whereas, their mean corpuscular volume (MCV) value and mean corpuscular hemoglobin $(\mathrm{MCH})$ value are slightly lower (Fucharoen and Winichagoon, 2000). However, if alleles are formed between $\mathrm{HbE}$ and $\beta$-thalassemia or $\mathrm{HbE} / \beta$-thalassemia (Vichinsky, 2007; Weatherall and Clegg, 2001b), the patient will have a chronic hemolytic anemia by red blood cell destruction and must receive frequent blood transfusions over lifetime, which may subsequently lead to iron overload. The excess iron may accumulate in various organs, which may cause complications and premature death (Fucharoen et al., 2000). HbE carriers are widely found in Thailand and Southeast Asia (Vichinsky, 2007) and $\beta$-thalassemia carriers are also found widely in this region. Thus, the chance of $\mathrm{HbE} / \beta$ thalassemia may occur very high. The World Health Organization (WHO) estimates that there will be 100,000 $\mathrm{HbE} / \beta$-thalassemia people in the next twenty years and will also happening in India, Sri Lanka, Malaysia, and South China. This health concerning has also spread to America and Europe as well by resulting from migration and intermarriage with Asian peoples (Vichinsky, 2007; Weatherall and Clegg, 2001a).

$\mathrm{HbE} / \beta$-thalassemia is classified as thalassemia intermedia, a group of patients with intermediate symptoms including: intermediate pallor with no need frequent blood transfusions, mild jaundice with a possibility they may have gallstones, osteoporosis/low bone mass in the case of iron overload. Some of them can be thalassemia major, which have severe symptoms including: prominent pallor; must receive blood transfusions from childhood, hypersplenism and spleenomegaly (at approximately 6-10 years of age) and need to remove the spleen or spleenoectomy; and iron overload will occur and must be constantly treated with medication. If the patient does not receive appropriate treatment and medication, severe symptoms will occur, such as, characteristic changes of the facial bones and skull, short stature, low body weight, retarded growth, osteoporosis/low bone mass and other complications may occur. Premature death may occur to infections or heart failure (Fucharoen et al., 2000).

$\mathrm{HbE}$ screening to prevent the incidence of $\mathrm{HbE} / \beta$ thalassemia is an important issue to which the government sector should pay attention. Detecting and measuring of $\mathrm{HbE}$ can be done through many techniques, such as cellulose acetate electrophoresis $(\mathrm{CAE})$, weak cation-exchange high performance liquid chromatography (HPLC) and capillary zone electrophoresis (CZE) (Clarke and Higgins, 2000; Winichagoon et al., 2008). These techniques are capable of efficiently detecting and measuring $\mathrm{HbE}$; however, these techniques are not capable of mass population screening. For example, cellulose acetate electrophoresis (CAE) has limitations due to it requiring many steps, from electrophoresis on cellulose acetate sheets, to dying and measuring the intensity of color. Furthermore, this test can only be conducted on 16 samples at a time. The HPLC and CZE methods are more suitable, such as a high throughput, and the HPLC method can present the ratio of hemoglobin $A 2$ and $F$, which are clearly seen, produce accurate measurement and require a short running time. $\beta$-thalassemia carriers have hemoglobin $A_{2}$ quantity between 4.0 to $10 \%$. $\mathrm{HbE}$ carriers have the $\mathrm{EA}$ hemoglobin characteristic and $\mathrm{HbE}$ quantity between 25 to $35 \%$. $\mathrm{HbE} / \beta$-thalassemia has the EF characteristic of hemoglobin, and $\mathrm{HbE}$ quantity is between 40 to $60 \%$. Homozygous $\mathrm{HbE}$ has the EE hemoglobin characteristic and $\mathrm{HbE}$ quantity between 85 to $100 \%$. These techniques require an automatic analyzer, which is expensive. For routine work, the $\mathrm{HbE}$ screening method that is easiest performed is the 2,6 dichlorophenol indophenols (DCIP) precipitation test, the basis of which is that the DCIP color will cause unstable hemoglobin, such as hemoglobin $\mathrm{E}$ and hemoglobin $\mathrm{H}$ to precipitate, which can be accomplished for a mass population. If this method is used together with the $0.36 \% \mathrm{NaCl}$ osmotic fragility test, the results of the hemoglobin $\mathrm{E}$ screening will be easier to interpret, especially in the densely populated or rural areas (Winichagoon et al., 2002; Wiwanitkit et al., 2002). Nevertheless, the DCIP test has issues with reading the results, namely that the dark blue color may make it difficult to read the precipitation and may requiring decolorization (Fucharoen et al., 2004). Furthermore, observing the precipitation may require usage of a light box and solid line written to read the results (Chapple et al., 2006). DCIP testing also requires appropriate temperature and accurate incubation time to avoid false positive results. Additionally, the DCIP color is an oxidizing agent which may deteriorate if stored for a long time (Hughes, 1983; VanderJagt et al., 1986). However, the reading of the results of this method can be improved by a clearing reagent called modified DCIP test (KKUDCIP), which is widely used at the present (Koranantakul et al., 1998).

The new HbE screening test or E-Sure test (Mitr Medical, Thailand) is based on ion exchange chromatography. After washing by other buffer systems at a different $\mathrm{pH}$ it is passed through the column, only hemoglobin $E$ will elute from the column, and is seen as red or pinkish solution in the test tube. This method is quick, specific, highly accurate and simple to perform and does not require any highly skilled technician. It can be used in the rural areas or in a community laboratory with limited resources (Tatu and Kasinrerk, 2012; Sanguansermsri et al., 1998). For the abovementioned reasons, the researcher was interested in the evaluation of the efficacy of the new $\mathrm{HbE}$ screening test (E-Sure) compared to the modified DCIP test (KKU-DCIP), which 

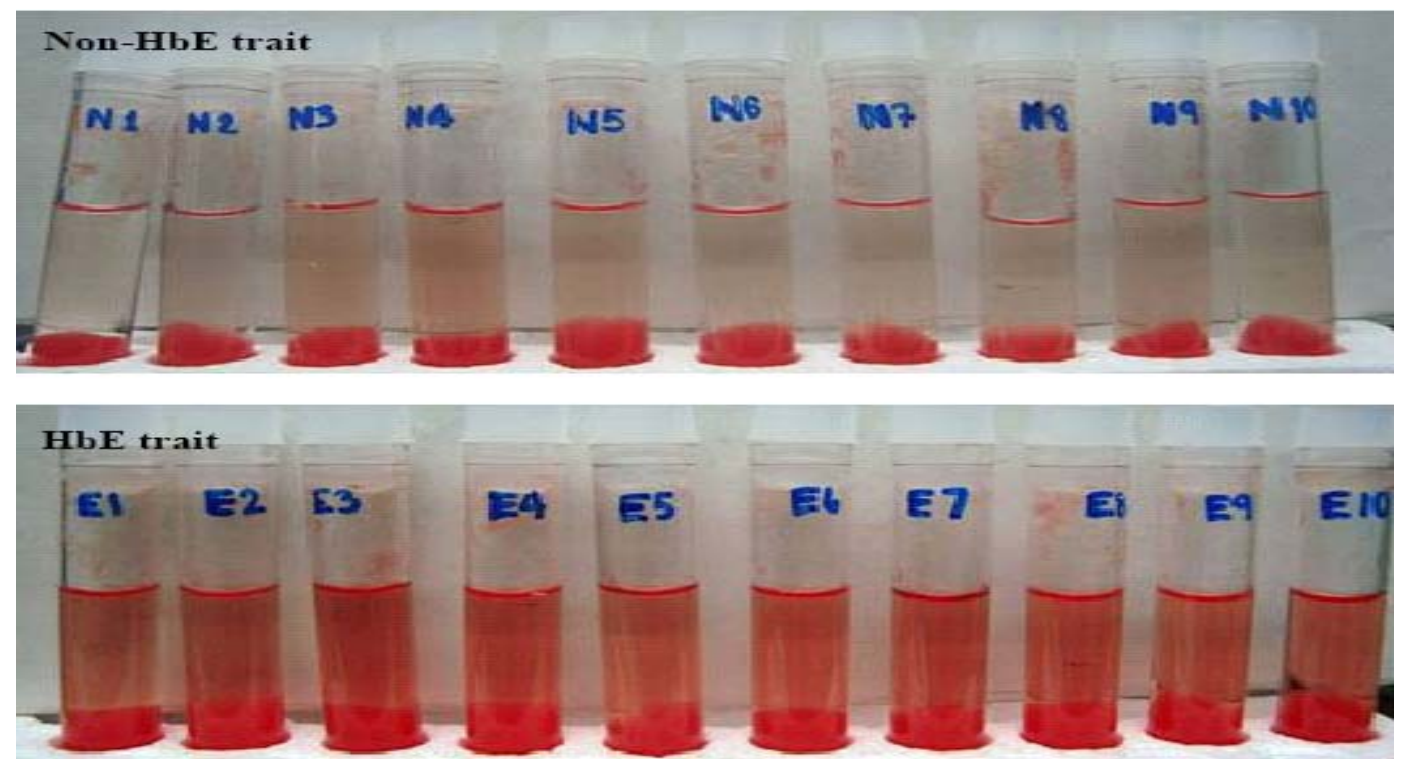

Figure 1. Presenting the results of hemoglobin $E$ carrier testing. The uncolored solution in the top row read as negative results, which interpreted as Non-HbE trait (top row). The reddish-pink colored solution in the bottom row read as positive results and interpreted as HbE trait (Tatu and Kasinrerk, 2012).

is at present the conventional method in community hospitals. The results are confirmed by capillary electrophoresis, which can confirm $\beta$-thalassemia carriers as well. The results of this study may be used as a guideline in selecting screening methods for $\mathrm{HbE}$ carriers to prevent $\mathrm{HbE} / \beta$-thalassemia risk at the community level.

\section{MATERIALS AND METHODS}

\section{Sample collection and selection for $\mathrm{HbE}$ screening test}

Ethylenediaminetetraacetic acid (EDTA) blood samples were collected from patients who came for check-ups at Kutchap Hospital and other hospitals with inter laboratory cooperation namely Nong Wuasaw hospital, Nong Saeng hospital and Pen hospital in Udon Thani Province, Thailand. This took place during the normal services of the hospital from October 2013 to February 2014. The research program had to pass the approval of the hospital directors and the Board of Human Research Ethics Committees of the hospital and all subjects gave written consent. The subjects were record the name, surname, $\mathrm{AN}, \mathrm{HN}$, ward, time and date of sample collection and clearly label the specimen tubes, as well as correctly giving the details of the specimen for testing in the request form. Before screening for $\mathrm{HbE}$, a complete blood count (CBC) was required as a routine laboratory test. The automatic analyzer was Celltac E MEK-7222 (Nihon Kohden, Japan), and the criterion of sample selection for $\mathrm{HbE}$ screening was lower corpuscular volume $(\mathrm{MCV}<80 \mathrm{fl})$.

\section{Evaluation of $\mathrm{HbE}$ screening tests and $\mathrm{HbE}$ confirmation}

The conventional $\mathrm{HbE}$ screening was performed by using the modified 2,6 dichlorophenol indophenols (DCIP) precipitation test (KKU-DCIP) method, which was based on that the DCIP will cause unstable hemoglobin to precipitate. This was conducted by adding 2-3 $\mathrm{ml}$ blood to test tubes, which were contained the anti-coagulant, EDTA and centrifuged at $100 \mathrm{~g}$ for $10 \mathrm{~min}$. The plasma was removed and $20 \mu \mathrm{l}$ of red blood cells was added to the test tube containing $5 \mathrm{ml}$ of DCIP reagent (KKU-DCIP Clear Reagent Kit). The blood and reagent were mixed by gently turning the test tubes and then warmed to $37^{\circ} \mathrm{C}$ for $1 \mathrm{~h}$. The results were then accurately read. Positive result was turbid solution and clear solution was negative result.

The new $\mathrm{HbE}$ screening test or E-Sure test is based on ion exchange chromatography according by characteristics, charge, and structure of each type of hemoglobin, which has different anions and cations. When the hemoglobin is placed in a particular buffer solution, the hemoglobin becomes electrically charged and then hemoglobin solution is passed through the column (diethyl aminoethyl [DEAE]) each hemoglobin molecules will be captured by the column. After washing by another buffer system at different a $\mathrm{pH}$, it is passed through the column, only hemoglobin $\mathrm{E}$ will elute from the column, and is seen as red solution in the test tube. Color intensity is dependent on the quantity of $\mathrm{Hb} \mathrm{E}$. It is notable that homozygous $\mathrm{HbE}$ (EE) gives a dark red color to the solution and heterozygous $\mathrm{HbE}(\mathrm{EA})$ gives a pinkish red color (Figure 1). The procedures of E-Sure were done by 1) open micro-column cap and then, put the micro-column in $13 \times 100 \mathrm{~mm}$ test tube 2) pipette $2 \mathrm{ml}$ of buffer A to micro-column 3) pipette $20 \mu \mathrm{l}$ of whole blood to buffer $A$ in micro-column 4) adding the stick of test kit to micro-column, press the stick to elute buffer $A$ into test tube until it will be finished and throw away buffer $A$ from test tube) 5 ) pipette $4 \mathrm{ml}$ of buffer $B$ to micro-column 6 ) adding the stick of test kit and press the stick to elute buffer $B$ into test tube and 7) read and interpret to results as describe on above.

Hemoglobin typing was used to distinguish normal, thalassemia and other types of hemoglobin abnormalities especially between $\beta$ thalassemia, heterozygous $\mathrm{HbE}(\mathrm{EA})$ and homozygous $\mathrm{HbE}(\mathrm{EE})$ and also to diagnose patients and carriers. The capillary electrophoresis was performed by an automatic analyzer, Capillarys II hemoglobin (Sebia electrophoresis, USA), which gave a high electrical charge to capillary tubes inside of the vessel. Both ends 
(A)

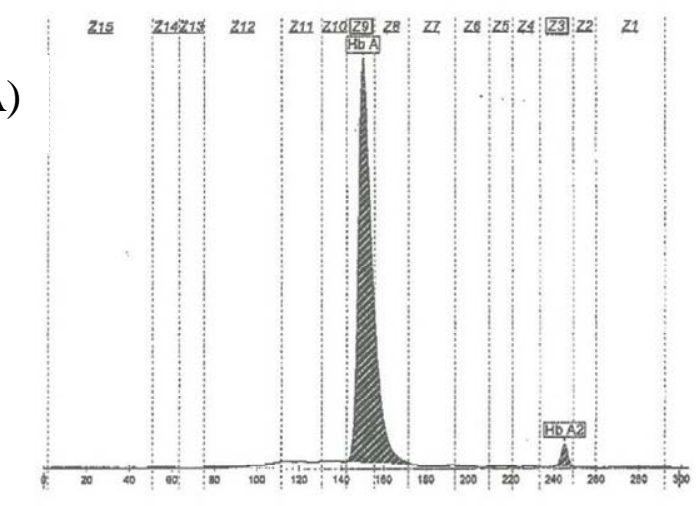

\begin{tabular}{lrrr} 
Fractions & $\%$ & Ref. $\%$ & Ref. g/dl \\
\hline Hb A & 97.2 & $96.8-97.8$ & \\
Hb A2 & 2.8 & $2.2-3.2$ &
\end{tabular}

(B)

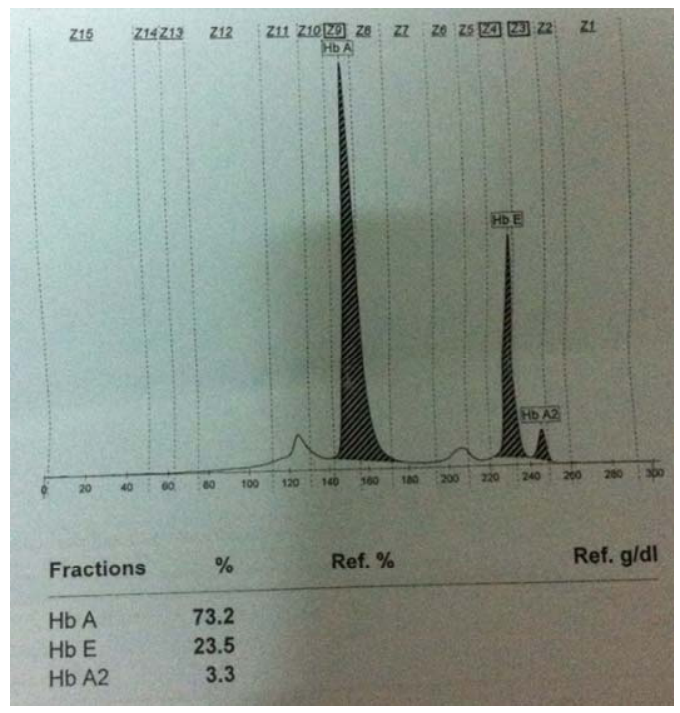

(C)

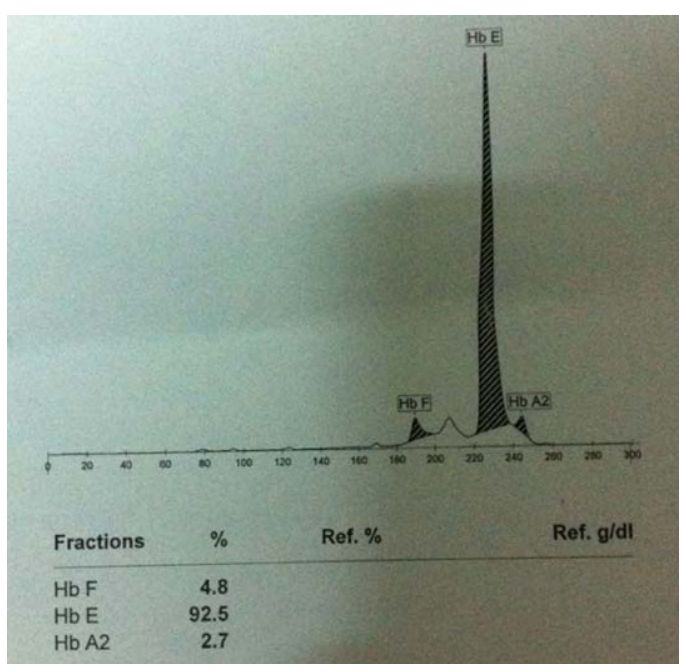

Figure 2. Electropherogram of hemoglobin typing by capillary electrophoresis. The results read as follows: A) $A_{2} A$; B) $E A$; C) $E E$, which were interpreted as normal, Heterozygous $\mathrm{HbE}$ and Homozygous $\mathrm{HbE}$, respectively. were immersed in electrolyte solution and caused the ions inside the sample to run from the positive to negative pole according to the strength of the electroosmotic flow (EOF). The zones of the separated solution after the electrical charge will pass the detection window and the changing of the signal from the detector (deuterium lamp) is sent to the data processor. This result is called an electropherogram. A report using a normal person's values as a reference is: $\mathrm{Hb} \mathrm{A}=79.4-93.4, \mathrm{Hb} \mathrm{A}_{2}<4.0, \mathrm{Hb} \mathrm{F}=0.0-1.2$. When each sample has been confirmed by hemoglobin typing, the new $\mathrm{HbE}$ screening (E-Sure) test is evaluated for sensitivity, specificity, positive predictive value, negative predictive value and efficiency (accuracy) of the analysis compared to modified DCIP (KKU-DCIP) method. The calculation of sensitivity, specificity, positive predictive value, negative predictive value and efficiency of tests were done by following formulae (TP = number of true positive; $\mathrm{TN}=$ number of true negative; $\mathrm{FP}=$ number of false positive and $\mathrm{FN}=$ number of false negative):

$\%$ Sensitivity $=[\mathrm{TP} / \mathrm{TP}+\mathrm{FN}] \times 100$

$\%$ Specificity $=[\mathrm{TN} / \mathrm{TN}+\mathrm{FP}] \times 100$

$\% \mathrm{PPV}=[\mathrm{TP} / \mathrm{TP}+\mathrm{FP}] \times 100$

$\% \mathrm{NPV}=[\mathrm{TP} / \mathrm{TP}+\mathrm{FP}] \times 100$

$\%$ Efficiency $=[\mathrm{TP}+\mathrm{TN} / \mathrm{TP}+\mathrm{FP}+\mathrm{TN}+\mathrm{FN}] \times 100$

\section{RESULTS}

$326 \mathrm{HbE}$ carriers $(\mathrm{MCV}<80 \mathrm{fl}$ ) were screened by the modified 2,6 dichlorophenol indophenols precipitation test (KKU-DCIP) and $\mathrm{HbE}$ screening test (E-Sure) test and confirmed with $\mathrm{Hb}$ typing by capillary electrophoresis to find false positives and false negatives from both screening methods. The hemoglobin electropherograms were presented as the $A_{2} A$, EA and $E E$ and interpreted to normal, heterozygous $\mathrm{HbE}$ and homozygous $\mathrm{HbE}$, respectively (Figure 2). After screening and confirming for $\mathrm{HbE}$ carriers, 226 cases of $\mathrm{HbE}$ carriers were found, including $234 \mathrm{HbE}$ trait and 32 homozygous $\mathrm{HbE}$ carriers (Table 1). When the efficacy of the KKU-DCIP screening method was compared to that of the $\mathrm{HbE}$ screening test (E-Sure) in community hospitals, it was found that the KKU-DCIP test had sensitivity, specificity, positive predictive, negative predictive and efficiency values of 95.1, 91.6, 98.1, 80.9 and $94.5 \%$, respectively. Whereas, $\mathrm{HbE}$ screening test, which had sensitivity, specificity, positive predictive, negative predictive and efficiency values of $99.2,96.7,99.2,96.7$ and $98.8 \%$, respectively (Table 2).

\section{DISCUSSION}

For the EDTA blood samples with low MCV (< $80 \mathrm{fl})$ values were presented anemic condition. MCV is one of the regular blood indices from $\mathrm{CBC}$ when applied together with screening test. There can increase the sensitivity of screening test to diagnose hemoglobin $E$ carriers (Yeo et al., 1994; Nadarajan et al., 2010; Sharma et al., 2013) and other thalassemia (Alkindi et al., 2011; Italia et al., 2014), such as, alpha-thalassemia carriers (Pornprasert et al., 2013). However, the many studies of 
Table 1. The numbers of normal and $\mathrm{HbE}$ carriers after confirmation $(\mathrm{N}=326)$.

\begin{tabular}{llc}
\hline Hb typing & Interpretation & Number of cases \\
\hline $\mathrm{A}_{2} \mathrm{~A}$ & Normal or Non clinical significant & 60 \\
$\mathrm{EA}$ & Heterozygous HbE & 234 \\
$\mathrm{EE}$ & Homozygous Hb E & 32 \\
\hline
\end{tabular}

Table 2. Two-by-two table showing diagnostic indices of KKU-DCIP and E-Sure screening tests to identify the hemoglobin $E$ trait among low MCV samples $(\mathrm{N}=326)$.

\begin{tabular}{|c|c|c|c|c|c|c|c|c|}
\hline \multirow{2}{*}{ Test } & \multirow{2}{*}{ Test result } & \multicolumn{2}{|c|}{$\mathrm{Hb}$ trait status } & \multirow{2}{*}{$\begin{array}{c}\text { Sensitivity } \\
(\%)\end{array}$} & \multirow{2}{*}{$\begin{array}{c}\text { Specificity } \\
\text { (\%) }\end{array}$} & \multirow{2}{*}{$\begin{array}{c}\text { PPV } \\
\text { (\%) }\end{array}$} & \multirow{2}{*}{$\begin{array}{l}\text { NPV } \\
(\%)\end{array}$} & \multirow{2}{*}{$\begin{array}{c}\text { Accuracy } \\
(\%)\end{array}$} \\
\hline & & Normal & $\mathrm{HbE}$ trait & & & & & \\
\hline \multirow{2}{*}{ KKU-DCIP } & Negative & 55 & 13 & \multirow{2}{*}{95.1} & \multirow{2}{*}{91.6} & \multirow{2}{*}{98.1} & \multirow{2}{*}{80.9} & \multirow{2}{*}{94.5} \\
\hline & Positive & 5 & 253 & & & & & \\
\hline \multirow{2}{*}{ E-Sure } & Negative & 58 & 2 & \multirow[t]{2}{*}{99.2} & \multirow[t]{2}{*}{96.7} & \multirow[t]{2}{*}{99.2} & \multirow[t]{2}{*}{96.7} & \multirow[t]{2}{*}{98.8} \\
\hline & Positive & 2 & 264 & & & & & \\
\hline
\end{tabular}

screening test for efficacy did not use the MCV value as the "cut off" before comparing between each screening methods. MCV can be used generally to screen thalassemia, which has long been widely practiced in eastern countries (Cao et al., 2002). At present, many hospitals use automatic red blood cell analyzer to test $\mathrm{CBC}$, which also gives MCV and Mean Corpuscular Hemoglobin $(\mathrm{MCH})$ values as it is convenient for laboratory work. Furthermore, red cell distribution width value, RDW of blood indices can screen thalassemia carriers and hemoglobin E carriers as well (Sharma et al., 2013). Nevertheless, using MCV and $\mathrm{MCH}$ values to screen thalassemia carriers or thalassemia were limited as far as results interpretation and distinguishing them from other conditions that were lower $\mathrm{MCV}$ and $\mathrm{MCH}$, e.g., iron deficiency anemia and chronic blood loss. Thalassemia screening by MCV values lower than $80 \mathrm{fl}$ and/or $\mathrm{MCH} 27 \mathrm{pg}$ were lower in sensitivity and specificity than screening by the one tube osmotic fragility test, OF and DCIP, because the Thai population has a number of $\mathrm{HbE}$ carriers with values $\mathrm{MCV} \geq 80 \mathrm{fl}$ and $\mathrm{MCH} \geq 27 \mathrm{pg}$ (Sanchaisuriya et al., 2005). In this study, 60 samples were interpreted to normal, but had low MCV values and interpreted to be a non- hemoglobin $E$ trait but possibly a heterozygous alpha thalassemia-1 trait with hemoglobin typing as $A_{2} A$ (normal). It was necessary to run further confirmatory tests by multiplex polymerase chain reaction (PCR) (Chang et al., 1991; Tongsong et al., 2000; Panyasai et al., 2002; Tungwiwat et al., 2006). Furthermore, other anemic conditions, such as chronic blood loss and iron deficiency anemia can also give low MCV results.

Wanapirak et al. (2009) compared the efficacy of the CMU-E method (Chiang Mai University-HbE, Thailand) and KKU-DCIP. The CMU-E method uses microcolumn chromatography, which is similar to E-Sure. The study results showed that CMU-E method produced less false positives because the results were easier to read and interpret than KKU-DCIP method, which must read positive results from murky solution, even though clearing reagent is used. Sometimes, false positive may be produced arising from the time to warm the solution and blood at $37^{\circ} \mathrm{C}$, which is too long, and may also give positive results for other unstable $\mathrm{Hb}$, such as, $\mathrm{HbH}$ disease.

$\mathrm{HbE}$ screening by the E-Sure test was newly developed by Tatu and Kasinrerk (2012) as a method with high sensitivity and specificity; however, this method has never been tested in community hospitals. This study used blood indices of MCV $(<80 \mathrm{fl})$ before using hemoglobin E E-Sure screening test kits, compared to the widely used method, KKU-DCIP. Community hospitals with limited highly skilled laboratory technician can also use the latter method; however, the reading and interpreting of results by E-Sure tests is easier and gives less false positives. The sensitivity, specificity, positive predictive, negative predictive and efficiency values are all higher than that of the KKU-DCIP method. However, results from hemoglobin $E$ screening by the E-Sure method still presented 2 false positives and 2 false negatives. This may have occurred from reusing columns too many times, or from the reading and interpretation of the technician performing the test.

The capital cost for E-Sure screening is lower (0.78$0.94 \mathrm{USD} /$ test) than the KKU-DCIP method (1.56-1.88 USD/test). If the E-Sure method would be used in place of the KKU-DCIP method, the capital costs for hospital labs would be reduced, especially community hospitals with limited budgets. Furthermore, hospitals with Quality Assurance (QA) policies, such as Hospital Accreditation (HA), ISO 15189 and Laboratory Accreditation (LA), among others, using the E-Sure method in place of the 
KKU-DCIP method could report results faster. The ESure test is takes 5 to 10 min turnaround time; whereas, the KKU-DCIP method takes an approximately $30 \mathrm{~min}$ turnaround time. This could increase the quality of health services. The government sector and relevant agencies support SMEs that conduct business involving biomedical material and health science appliances to develop the biomedical material and industry. E-Sure tests were developed under the support of the National Innovation Agency (NIA), Thailand. The researcher perceives that there are benefits of this study to provide information to support the quality of products currently on the market, and also support Thai innovations.

\section{Conclusion}

The new HbE screening test, E-Sure test is a screening test with higher efficacy, as well as being more convenient and easier to interpret than the KKU-DCIP test. Furthermore, no additional special appliances are needed to conduct the test. This method is suitable for hemoglobin E carrier screening in community hospital laboratories.

\section{Conflict of Interests}

The author(s) have not declared any conflict of interests.

\section{ACKNOWLEDGEMENTS}

Author is grateful to Kutchap Hospital, Mungpry, Kutchap, Udon-thani, Thailand, for the provision of clinical specimens and the automatic blood analyzer. I would like to sincerely thank all the staff of the Division of Clinical Pathology and all volunteers who provided clinical specimens in this study. I would like also to thank the Research and Development Institute, Suan Sunandha Rajabhat University for funding support.

\section{REFERENCES}

Alkindi S, Pathare A, Al-Madhani A, Al-Zadjali S, Al-Haddabi H, Al-Abri Q, Gravell D, Mathew M, Krishnamoorthy R (2011). Neonatal Screening: Mean haemoglobin and red cell indices in cord blood from Omani neonates. Sultan Qaboos Univ. Med. J. 11(4):462-469. PMid:22087394 PMCid:PMC3206748

Cao A, Rosatelli MC, Monni G, Galanella R (2002). Screening for thalassemia: a model of success. Obstet. Gynecol. Clin. North Am. 29(2):305-328. http://dx.doi.org/10.1016/S0889-8545(01)00006-7

Chang JG, Lee LS, Lin CP, Chen PH, Chen CP (1991). Rapid diagnosis of alpha-thalassemia- 1 of southeast Asia type and hydrops fetalis by polymerase chain reaction. Blood 78(3):853-854.PMid:1859898

Chapple L, Harris A, Phelan L, Bain BJ (2006). Reassessment of a simple chemical method using DCIP for screening for haemoglobin E. J. Clin. Pathol. 59(1):74-76. http://dx.doi.org/10.1136/jcp.2005.027961; $\quad$ PMid:16394284 PMCid:PMC1860247
Clarke GM, Higgins TN (2000). Laboratory investigation of hemoglobinopathies and thalassemias: Review and update. Clin. Chem. 46(8):1284-1290. PMid:10926923

Fucharoen G, Sanchaisuriya K, Sae-ung N, Dangwibul S, Fucharoen S (2004). A simplified screening strategy for thalassaemia and haemoglobin $\mathrm{E}$ in rural communities in South-east Asia. Bull. World Health Organ. 82(5):364-372. PMid:15298227 PMCid:PMC2622836

Fucharoen S, Ketvichit P, Pootrakul P, Siritanaratkul N, Piankijagum A, Wasi P (2000). Clinical manifestation of beta-thalassemia/hemoglobin E disease. J. Pediatr. Hematol. Oncol. 22(6):552-557. http://dx.doi.org/10.1097/00043426-20001100000022;PMid:11132229

Fucharoen S, Winichagoon P (1992). Thalassemia in Southeast Asia: problem and strategy for prevention and control. Southeast Asian J. Trop. Med. Public Health. 23(4):647-655. PMid:1298071

Fucharoen S, Winichagoon P (2000). Clinical and hematologic aspects of hemoglobin $E$ beta-thalassemia. Curr. Opin. Hematol. 7(2):106$112 . \quad$ http://dx.doi.org/10.1097/00062752-200003000-00006 PMid:10698297

Hughes DE (1983). Titrimetric determination of ascorbic acid with 2,6dichlorophenol indophenols in commercial liquid diets. J. Pharm. Sci. 72(2):126-129. PMid:6834248

Italia K, Upadhye D, Dabke P, Kangane H, Colaco S, Sawant P, Nadkarni A, Gorakshakar A, Jain D, Italia Y, Ghosh K, Colah R (2014). Clinical and hematological presentation among Indian patients with common hemoglobin variants. Clin. Chim. Acta. 431:4651. http://dx.doi.org/10.1016/j.cca.2014.01.028; PMid:24508621

Kor-anantakul O, Suwanrath CT, Leetanaporn R, Suntharasaj T, Liabsuetrakul T, Rattanaprueksachart R (1998). Prenatal diagnosis of thalassemia in Songklanagarind Hospital in southern Thailand. Southeast Asian J. Trop. Med. Public Health 29(4):795-800. PMid:10772567

Nadarajan VS, Sthaneshwar P, Jayaranee S (2010). RBC-Y/MCV as a discriminant function for differentiating carriers of thalassaemia and $\mathrm{HbE}$ from iron deficiency. Int. J. Lab. Hematol. 32(2):215-221. http://dx.doi.org/10.1111/j.1751-553X.2009.01174.x; PMid:19566741

Panyasai S, Sringam P, Fucharoen G, Sanchaisuriya K, Fucharoen S (2002). A simplified screening for alphathalassemia1 (SEA type) using a combination of a modified osmotic fragility test and a direct PCR on whole blood cell lysates. Acta Haematol. 108(2):74-78. http://dx.doi.org/10.1159/000064746; PMid:12187024

Pornprasert S, Punyamung M, Treesuwan K (2013). Criteria for detection of alpha-thalassemia-1 Thai type deletion in routine laboratory. Clin. Lab. 59(11-12):1423-1427. PMid:24409681

Sanchaisuriya K, Fucharoen $S$, Fucharoen $G$, Ratanasiri $T$, Sanchaisuriya P, Changtrakul Y, Ukosanakarn U, Ussawaphark W Schelp FP (2005). A reliable screening protocol for thalassemia and hemoglobinopathies in pregnancy: An alternative approach to electronic blood cell counting. Am. J. Clin. Pathol. 123(1):113-118. http://dx.doi.org/10.1309/FUF9EVGQ24V1PKTP; PMid:15762286

Sanguansermsri T, Sankapreecha C, Steger HF (1998). Hb E screening test. Thai J. Hematol Transfus. Med. 8(2):215-21.

Sharma A, Marwah S, Buxi G, Yadav R (2013). Hemoglobin e syndromes: emerging diagnostic challenge in north India. Indian $\mathrm{J}$. Hematol. Blood Transfus. 29(1):21-25. http://dx.doi.org/10.1007/s12288-011-0140-9; PMCid:PMC3572259

Tatu T, Kasinrerk W (2012). A novel test tube method of screening for hemoglobin E. Int. J. Lab. Hematol. 34(1):59-64. http://dx.doi.org/10.1111/j.1751-553X.2011.01357.x; PMid:21883965

Tongsong T, Wanapirak C, Sirivatanapa $P$, Sanguansermsri T, Sirichotiyakul S, Piyamongkol W, Chanprapaph P (2000). Prenatal control of severe thalassaemia: Chiang Mai strategy. Prenat. Diagn. 20(3):229-234. $\quad$ http://dx.doi.org/10.1002/(SICI)10970223(200003)20:3<229::AID-PD790>3.0.CO;2-3

Tungwiwat W, Fucharoen S, Fucharoen G, Ratanasiri T, Sanchaisuriya K (2006). Development and application of a real-time quantitative PCR for prenatal detection of fetal alpha(0)-thalassemia from maternal plasma. Ann. N. Y. Acad. Sci. 1075:103-107. http://dx.doi.org/10.1196/annals.1368.013; PMid:17108198

VanderJagt DJ, Garry PJ, Hunt WC (1986). Ascorbate in plasma as measured by liquid chromatography and by 
dichlorophenolindophenol colorimetry. Clin. Chem. 32(6):1004-1006. PMid:3708799

Vichinsky E (2007). Hemoglobin E syndromes. Hematology Am. Soc. Hematol. Educ. Program. 79:79-83. http://dx.doi.org/10.1182/asheducation-2007.1.79; PMid:18024613

Wanapirak C, Sirichotiyakul S, Luewan S, Srisupundit K, Tongsong T (2009). Comparison of the accuracy of dichlorophenolindophenol (DCIP), modified DCIP, and hemoglobin E tests to screen for the $\mathrm{HbE}$ trait in pregnant women. Int. J. Gynaecol. Obstet. 107(1):59-60. http://dx.doi.org/10.1016/j.ijgo.2009.04.020; PMid:19477441

Wasi P (1981). Haemoglobinopathies including thalassemia. Clin. Haematol. 10(3):707-729. PMid:7030550

Weatherall DJ, Clegg JB (2001a). Inherited haemoglobin disorders, an increasing global health problem. Bull. World Health Organ. 79(8):704-712. PMid:11545326 PMCid:PMC2566499

Weatherall DJ, Clegg JB (2001b). The Thalassaemia Syndromes, 4th edn. Blackwell Scientific, Oxford. http://dx.doi.org/10.1002/9780470696705
Winichagoon P, Svasti S, Munkongdee T, Chaiya W, Boonmongkol P, Chantrakul N, Fucharoen S (2008). Rapid diagnosis of thalassemias and other hemoglobinopathies by capillary electrophoresis system. Translational Res. 152:178-84. http://dx.doi.org/10.1016/j.trsl.2008.08.004; PMid:18940720

Winichagoon P, Thitivichianlert A, Lebnak T, Piankijagum A, Fucharoen $S$ (2002). Screening for the carriers of thalassemias and abnormal hemoglobins at the community level. Southeast Asian J. Trop. Med. Public Health. 33(Suppl. 2):145-150. PMid:12755285

Wiwanitkit V, Suwansaksri J, Paritpokee N (2002). Combined one-tube osmotic fragility (OF) test and dichlorophenol-indolphenol (DCIP) test screening for hemoglobin disorders, an experience in 213 Thai pregnant women. Clin. Lab. 48(9-10):525-528. PMid:12389713

Yeo GS, Tan KH, Liu TC (1994). Screening for beta thalassaemia and $\mathrm{HbE}$ traits with the mean red cell volume in pregnant women. Ann. Acad. Med. Singapore 23(3):363-366. PMid:7944251 